\title{
Characteristics volatiles of cassava flours and their relationship to parameters other, process and geographical origin: a preliminary study
}

\author{
Diego Roberto da Cunha Pascoal ${ }^{1 \star}$ (D), Lídia Eloy Moura ${ }^{1}$, Jaff Ribeiro da Silva ${ }^{1}$, Denilson de Jesus Assis ${ }^{2}$, \\ Samantha Serra Costa ${ }^{3}$, Janice Izabel Druzian ${ }^{1,2}$
}

\begin{abstract}
The aim of this study was the physicochemical characterization of traditional cassava flours from Copioba Valley in Reconcavo Baiano (Northeast Brazil). Samples were collected in flour houses and analyzed by official methods of proximate composition and chromatography and spectroscopy for fatty acids and volatile compounds. Regardless of geographical origin (inside and outside the Valley) and processing type (Copioba and Common flour), there were no significant differences in water activity, ash, crude protein, starch, carbohydrates or acidity. By contrast, significant differences were observed in moisture, particle size, total lipids, palmitic acid and volatile compounds, mainly nonanal. Discriminant classification by principal component analysis according to origin and processing was obtained using this differentiation. These parameters are important for associations of reputation, authenticity and differentiation with the Protected Geographical Indication of Copioba cassava flours.
\end{abstract}

Keywords: Manihot esculenta Crantz; fingerprint; lipid oxidation; headspace GC-MS; Copioba Valley; Reconcavo Baiano.

Practical Application: Physicochemical profiling to differentiate geographic origin of cassava flour.

\section{Introduction}

Processing methods such as roasting or drying, after fermentation, have been developed to decrease the toxicity of cassava and to produce safe foodstuffs (Gleadow \& Møller, 2014; Rosales-Soto et al., 2016). In Brazil several processing systems for cassava root are used producing, consequently, cassava flours with different compositions/quality. This is the case of the traditional cultivation performed by small farmers in semi-arid areas of the Northeast or Amazon, and the large-scale cultivation in the south (Olsen \& Schaal, 1999; Dias \& Leonel, 2006).

The Copioba Valley (CV) in the Reconcavo Baiano produces a very reputable cassava flours, called "Copioba flour", and are considered as quality reference. The flours are produced manually or on a small scale in flour mills called "flour houses". These flours have a consumer's widespread acceptance due to their unique organoleptic characteristics (Brasil, 2013).

The geographical origin proof of foodstuffs is a challenging research area, particularly for traditional rural products. The Protected Geographical Indication (PGI) allows market recognition and add value to these products, ensuring quality for consumers (Anderson \& Smith, 2002; Melucci et al., 2016; Su et al., 2016). Currently about 74 products are PGI registered with the Brazilian INPI (Instituto Nacional de Propriedade Industrial), being 50\% granted in the last 7 years (Serviço Brasileiro de Apoio às Micro e Pequenas Empresas, 2021).

Thus, the present study aimed to determine quality parameters/identity specifications of cassava flours produced by two different processing methodologies in the CV and neighboring geographic areas from the Reconcavo Baiano (Northeastern Brazil). Consequently, to contribute to the origin certification of the product this study is based mainly on fatty acid and volatile profiles.

\section{Materials and methods}

\subsection{Sampling}

This work is part of the project "Qualidade, identidade e notoriedade da farinha de mandioca de Nazaré das Farinhas, Bahia: uma contribuição para indicação geográfica" funded by Fundação de Amparo à Pesquisa do Estado da Bahia. The cassava flour samples were collected inside and outside of the $\mathrm{CV}$, region that crosses the municipalities of São Felipe, Maragogipe and Nazaré (latitude $13^{\circ} 01^{\prime} 34.4^{\prime \prime}-12^{\circ} 71^{\prime} 57.0^{\prime \prime}$; longitude $039^{\circ} 17^{\prime} 58.3^{\prime \prime}$ $038^{\circ} 80^{\prime 2} 25.9^{\prime \prime}$, Reconcavo Baiano, Northeastern Brazil) (Figure 1). The processing steps were characterized. Samples were collected in a randomized manner. 

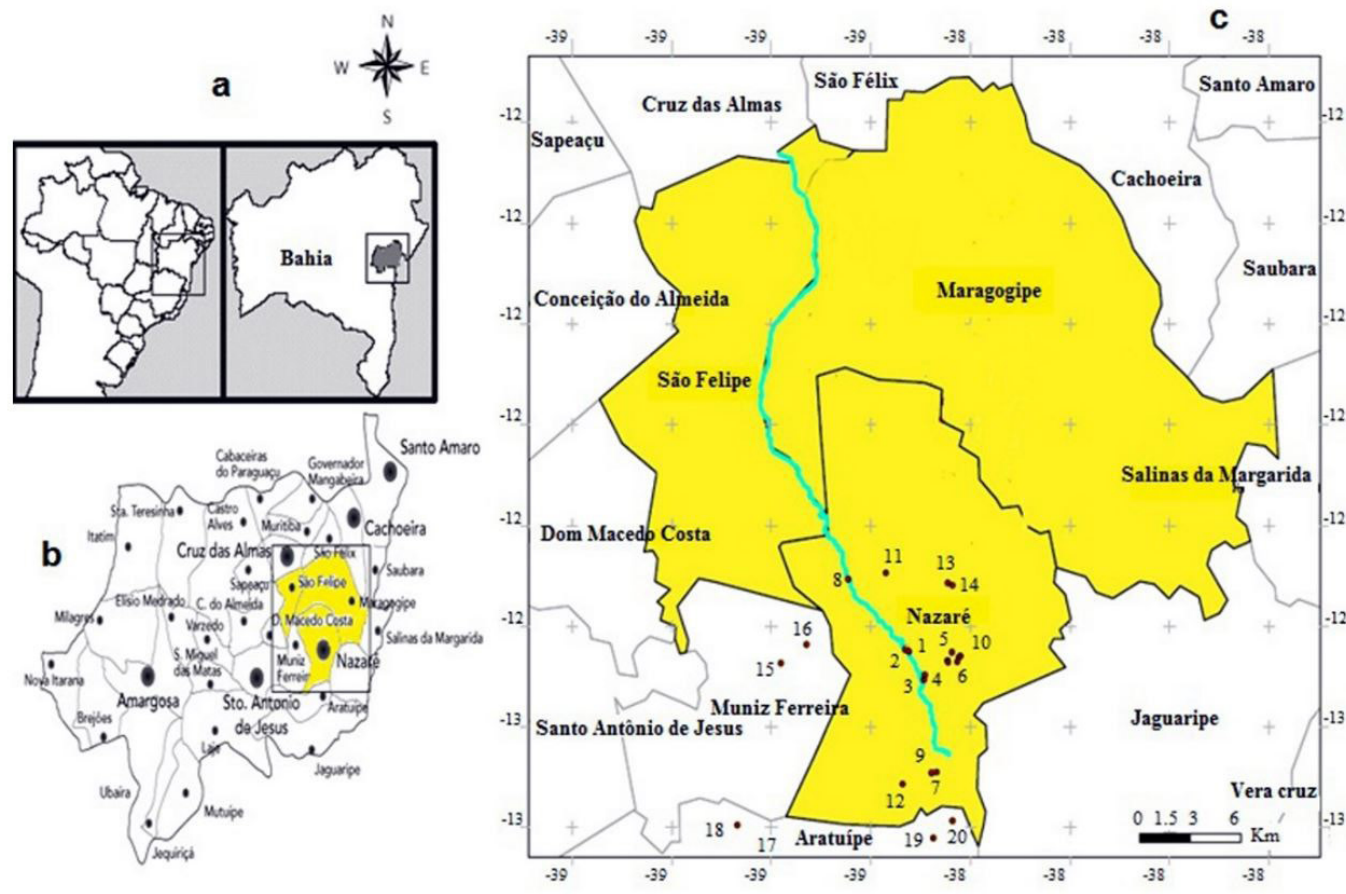

Valley copioba and its flour production houses

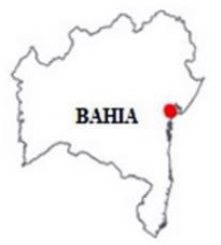

Legend

- Flour production house Copioba River

3 Copioba Valley Minicipalities 3 Municipal boundaries

Figure 1. Geographical origin of the cassava flour samples: a) Bahia State/Northeastern Brazil, b) Reconcavo Baiano and c) Copioba Valley (Nazaré, Maragogipe and São Felipe).

\subsection{Proximal composition and identity/quality parameters}

The moisture (925.09), crude protein (Micro-Kjeldahl, 926.86, $\mathrm{N} x$ 5.75), ash (923.03) contents and total acidity by titration with $\mathrm{NaOH}$ were determined according to literature (Association of Official Analytical Chemists, 2005). The total lipid content (Bligh \& Dyer, 1959) was esterified (Joseph \& Ackman, 1992). The total carbohydrate content was obtained by difference. The water activity $\left(\mathrm{a}_{\mathrm{w}}\right)$ was determined using AquaLab Lite. Starch was determined by acid hydrolysis followed by titration with Fehling reagents (Instituto Adolfo Lutz, 2008). The particles size distribution was determined of according to literature (Dias \& Leonel, 2006).

\subsection{Fatty acid composition by GC-FID}

The fatty acid methyl esters (FAMES) were separated on a gas chromatograph (Varian, CP 3800) equipped with a CP-Wax column $(25 \mathrm{~m} \mathrm{x} 0.25 \mathrm{mM} \times 0.20 \mu \mathrm{m})$ and flame ionization detector (GC-FID). The temperature was initially set at $150^{\circ} \mathrm{C}(16 \mathrm{~min})$ and then increased at $2^{\circ} \mathrm{C} /$ minute to $180^{\circ} \mathrm{C}$ (maintained for 25 $\min$ ), $5^{\circ} \mathrm{C} / \mathrm{min}$ to $210^{\circ} \mathrm{C}$ (maintained for $10 \mathrm{~min}$ ) and $10^{\circ} \mathrm{C} /$ $\min$ to $230^{\circ} \mathrm{C} 16 \mathrm{~min}$ ). The injector was set at $250^{\circ} \mathrm{C}$ and the detector at $280^{\circ} \mathrm{C}$. The carrier gas was Helium at a flow rate of $1.0 \mathrm{~mL} / \mathrm{min}$. The FAMEs were identified by retention times $\left(\mathrm{t}_{\mathrm{R}}\right)$ comparison of the samples peaks with those of FAME standards Sigma-Aldrich (USA). Assay carried out in triplicate.

\subsection{Volatile compounds profile by headspace GC-MS}

Flour samples $(3.0 \mathrm{~g})$ were stored in hermetically sealed vials and analyzed in a Headspace injector (HS, model Perkin Elmer Turbo Matrix 16) coupled to a GC-MS equipment (Perkin
Elmer, model Clarus $500 \mathrm{MS})$. The HS extraction was operated at $100{ }^{\circ} \mathrm{C} / 60 \mathrm{~min}$ with the needle and transfer line at $150{ }^{\circ} \mathrm{C}$, a pressurization time of $3 \mathrm{~min}$ and an injection time of $1 \mathrm{~min}$. The injection was performed at $150^{\circ} \mathrm{C}$ in a splitless vaporization chamber with a $2-\mathrm{mM}$ internal diameter. The separation was performed on an HP-FFAP column $(50 \mathrm{~m} \times 0.2 \mathrm{mM} \times 0.33 \mu \mathrm{m})$ at $50{ }^{\circ} \mathrm{C} / 20 \mathrm{~min}$, followed by increments of $3{ }^{\circ} \mathrm{C} / \mathrm{min}$ to $200^{\circ} \mathrm{C}$ and $10^{\circ} \mathrm{C} / \mathrm{min}$ to $230^{\circ} \mathrm{C}$ (maintained for $7 \mathrm{~min}$ ), in a total of $80 \mathrm{~min}$. Helium at $1 \mathrm{~mL} / \mathrm{min}$ was used as the carrier gas. The molecules were fragmented by electron impact $(\mathrm{EI} 70 \mathrm{eV})$. The peaks of volatiles present in the samples were identified by comparison of their mass spectra with the spectra of the reference National Institute of Standards and Technology (NIST) database and results expressed as peak areas.

\subsection{Treatment of data}

Data from samples of 4 treatments were evaluated: reference Copioba flour from the Copioba Valley; Copioba flour from the Copioba Valley; Common flour from the Copioba Valley; and Copioba flour from outside the Copioba Valley (neighboring regions to the Valley). Data were submitted to descriptive statistics test and analysis of variance. For the mean comparison between the different treatments, the Kruskal-Wallis test $(\mathrm{p}<0.05)$ was applied, where the null hypothesis was that the samples were from the same population, i.e., there are no differences among the 4 treatments. For the rejected null hypotheses, the Mann-Whitney test $(\mathrm{p}<0.05)$ was used. Considering the small sample number, the data set of the centesimal composition was randomized 10,000 times to determine if a sample was random or not (Manly, 2006). The Spearman's rho correlation coefficient and coefficients of determination $\left(\mathrm{R}^{2}\right)$ were calculated to evaluate 
the possible correlations between quantitative variables. The correlation coefficient greater than 0.8 was used as a criterion for eliminating a variable from the principal component analysis (PCA), this assay was performed using PAST software (Hammer et al., 2001). For cluster analysis was used Ward's method of according to literature (Xu, et al., 2016).

\section{Results and discussion}

\subsection{Composition and identity/quality parameters}

Flour production in the $\mathrm{CV}$ uses a traditional process that includes manual steps, with or without the use of electric equipment, and has expanded throughout the Reconcavo Baiano. Our research group conducted a data survey of the CV's "flour houses", being identified 72 production units, of which $94 \%$ in the Nazaré municipality. These production units are, in general, family-run businesses, with production capacities between 100 and $1000 \mathrm{~kg}$ flour/day (Silva et al., 2017). Samples were collected from 14 of these "flour houses" inside the CV. In general, the traditional processing of both Copioba and Common flours has 10 steps, as follows: roots withdrawal from soil, their transport and reception, peeling, triturating or milling to obtain a paste, pressing, mass pulverizing, drying or roasting, sieving, packaging and storage. This technological process of manufacture classifies as "Seca" the identity of Copioba flour (Brasil, 2011).

After harvesting, the roots are peeled and ground using a hammer mill. The pressing step eliminates a substantial part of the water, increasing the surface exposed to hot air drying, thus, the identity of cassava flours are characterized after drying. This processing step is very important for the genuineness of Copioba flour because it is responsible for the fermentation process that increases the acidity of cassava flours from Valley (Rosales-Soto et al., 2016). Some "flour houses" use manual ovens for samples roasting, but in most of them motorized ovens with constant rotation and controlled speed are used. Then flour is sifted through sieves to determine the particle size. Packaging is performed in $50 \mathrm{~kg}$ plastic bags for bulk distribution, without individual packaging.

Small-scale flour processing is prevalent at the CV, where, e.g., roots are peeled manually using knives. However, largerscale processing with scarifying equipment may be found outside the CV. The processing of the "first-generation" cassava flour was totally manual. A small number of families are call the second-generation (Samples 1 and 2), because the production of traditional Copioba flour in the Valley uses electric mills for grating. Moreover, is mostly characterized by 3 consecutive cycles of roasting performed in manually controlled wood-fired ovens (artisanal), with gradual temperature increases, interleaved by 3 cycles of sieving. The traditional process is more time consuming because it involves the manual spreading of the flour onto a circular steel plate and requires 3 to 8 hours to dry a batch of about $90 \mathrm{~kg}$ of flour. At most "flour houses" in and outside the $\mathrm{CV}$, manual ovens have been replaced by wood-fired ovens with electric controls, it is call processing of "third-generation" (Samples 3 to 20). However, in these wood-fired ovens, the roasting temperature for Copioba flours initially tends to be lower than than used for Common flours, but with a gradual increase.
This difference may be one of the main factors responsible for the lower ranges of moisture and $\mathrm{a}_{\mathrm{w}}$ contents of Copioba flours (Table 1). In the third-generation processing sieving is performed only once, following flour roasting that guarantees the ongoing notoriety of the CV flour.

According to Table 1, different values were determined in $\mathrm{a}_{\mathrm{w}}$ (0.10 - 0.61), moisture (0.96-8.42\%), ash (0.83-1.21\%), total lipid $(0.17-0.62 \%)$, crude protein $(0.50-1.45 \%)$ and carbohydrate contents (89.31 - 96.84\%) of the flours tested. All values were in accordance with Codex guidelines (2013) and with previously reported values (Dias \& Leonel, 2006; Food and Agriculture Organization, 1989; Rosales-Soto et al., 2016). These differences may also be justified by cassava genotype and environmental conditions (Charles et al., 2005; Burns et al., 2012).

The moisture, ash and protein contents of cassava flours produced at Reconcavo Baiano are the result of Legislation (moisture $<13 \%$, ash $\leq 1.4 \%$ and protein $<1.2 \%$ ) and are classified as the dry group (Brasil, 2011). The moisture interval is smaller than that of flours produced in other Brazilian regions $(1.45 \pm 0.07$ to $11.31 \pm 0.16 \%)$ and is characteristic of small-scale production without severe controls in the producing processes (Dias \& Leonel, 2006). The starch content interval ranged from 79.6 to $87.9 \%$, which is lower than the one presented by flours of the 31 cassava varieties from Ejura in the Ashanti Region that ranged from 67.92 to $88.11 \%$ (Aryee et al., 2006).

However, there were no significant differences in proximal parameters among the 4 treatments ( $p<0.05$ ), except for moisture and total lipids (Table 1). The average moisture of Samples 1 and 2 was significantly lower $(\mathrm{p}<0.05)$ than that of the other flour groups. This difference may be mostly related to the traditional drying process (3 roasting cycles with manual control and 3 sieving cycles), which results in the characteristic crunchiness that defines the product's identity. This parameter and the characteristic color are used by consumers as the main identity and notoriety parameters of Copioba flour from the Copioba Valley. Variations in moisture and $\mathrm{a}_{\mathrm{w}}$, associated with small changes in minor components, such as lipids, proteins and ashes, result in large quality differences depending on the type of processing used (Kulchan et al., 2010).

In the production of cassava flour in the dry group, in most regions of Brazil, following the reception of roots, all steps are performed without interruption (Dias \& Leonel, 2006). However, interrupted production processes are used at the "flour houses" in the CV and Reconcavo Baiano for both Copioba and Common flours. The ground cassava roots are left at room temperature for long periods, sometimes overnight, especially during the pressing stage, resulting in spontaneous fermentation and increased acidity. Most of the flours (95\%) were classified as higher acidity, with values ranging from 4.55 to 6.53 meq NaOH $0.1 \mathrm{~N} / 100 \mathrm{~g}$ (>3.0 meq NaOH $0.1 \mathrm{~N} / 100 \mathrm{~g}$; Brasil, 2011), without significant differences $(\mathrm{p}<0.05)$ among the 4 treatments (Table 1).

In addition to the significant variations $(p<0.05)$ of the moisture and total lipids, there also were observed in particle size distribution (Figure 2), indicating that the flours did not belong to the same population. The Copioba flours produced 


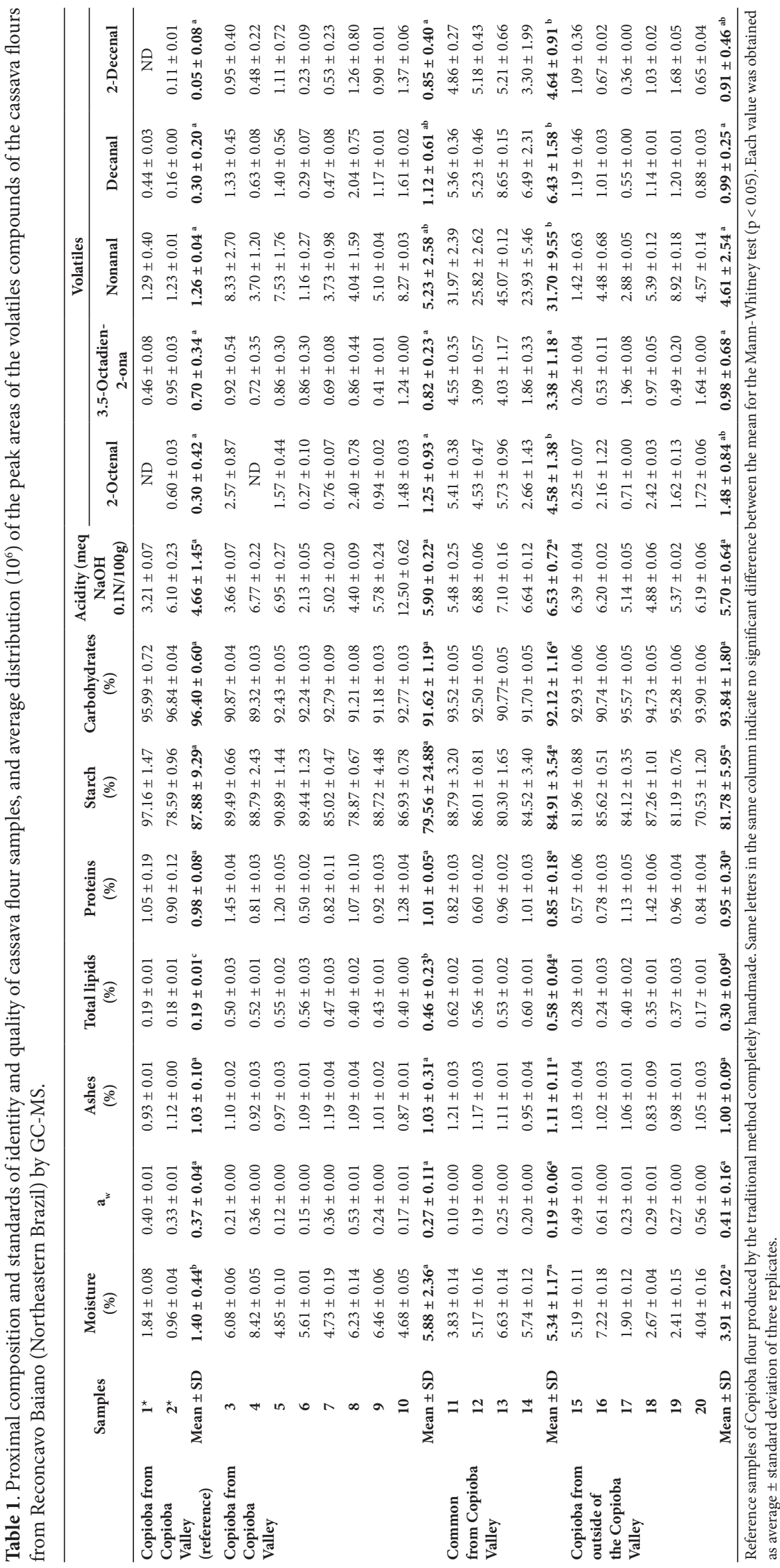


inside of the Valley (samples 1 to 10) showed similar average particle size distributions. The flours produced in the Valley presented higher percentages of smaller size particles (60 to 70\% between 0.075 and $0.250 \mathrm{~mm}$ ) than the Copioba flours produced outside the Valley $(46 \%>0.25 \mathrm{~mm})$. All flours analyzed were "Fine" because 86 to $100 \%$ of particles passed through the 0.425 mm mesh sieve (Brasil, 2011).

Differences in the moisture and distribution of particles may affect texture because water migration is influenced by the drying time, temperature and amylose content, among other factors, which can be influencer the sensorial perception of flour. During the drying process, a solid material is produced by stabilization of the gelatinized starch matrix and water evaporation. These phenomena determine the water amount retained in the flour, which will affect the retrogradation speed and the flour characteristics. A shorter drying time will produce a viscous product with a higher amount of superficial water, due to faster water migration. However, a longer drying time will dehydrate the product, depending on the evaporation speed, increasing crunchiness (Yao et al., 2003; Kojima et al., 2004; Kulchan et al., 2010).

The differences in this step of production are dependent of the time that the flour remains in contact with the drying equipment (metal/ steel plaque), drying temperatures and particles size, compared with Common flour. Water activity higher than 0.5 may be considered critical to flour crispness (Kulchan et al., 2010). The different particle sizes, associated with small differences in $a_{w}$ moisture, total lipids and starch contents (Table 1, Figure 2), may be the flour identity parameters, explaining the consumer's preference for Copioba cassava flour. These flours are related to smaller particles with certain ranges of $\mathrm{a}_{\mathrm{w}}$ and total lipid content. These characteristics may contribute to decrease lipid oxidation, strengthening the gel structure, increasing cohesion, producing crunchier.

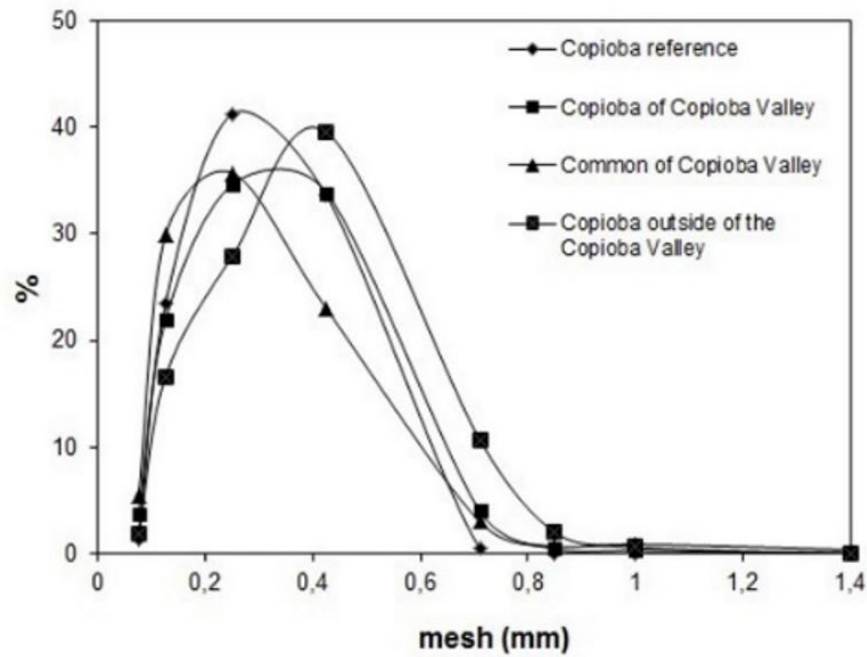

The total lipid contents were significantly different $(\mathrm{p}<$ 0.05 ) of the flours in the 4 treatments analyzed. Thus, different levels of lipid degradation may occur, especially if degradation is associated with certain ranges of $\mathrm{a}_{\mathrm{w}}$. This variation could explain the organoleptic characteristics of the different types of flour and their higher or lower notoriety. Hydroperoxide formation is catalyzed by metals and is promoted by high temperatures and in the presence of oxygen, which are conditions present at flour drying. Higher amounts of unsaturated lipid (\%) were associated with higher volatile percentages. The fatty acid profiles were determined (Figure 3), where all flours presented the same fatty acids. The unsaturated fatty acids were the more abundant highlighting C18:1n9, C18:2n6 and C18:3n 3 and between the saturated fatty acids were C12:0, C14:0, C16:0 and C18:0 being the palmitic acid the majority, where the flours from outside the CV had a higher concentration. It was verified that the total saturated and unsaturated fatty acids of the Copioba flour produced outside the Copioba Valley were significantly different from the other groups in study $(\mathrm{p}<0.05)$. Common flours presented the highest percentages of total lipids and the highest unsaturated fatty acid percentages. This difference may result in increased oxidation trends.

The Copioba cassava flours samples produced inside and outside the Valley, especially the reference Copioba flours (traditional production process), presented more process stable values, such as $\mathrm{a}_{\mathrm{w}}(0.27-0.41)$ and lower total lipids concentration (0.19- $0.46 \%)$. As lipid oxidation leads to the formation of offflavors, it seems of utmost importance to evaluate the volatile compounds when unstable polyunsaturated lipids are present. The oxidation mechanisms in oils, fat and model systems are known and are rather complex (Frankel et al., 1992; Jeong et al., 2010). However, the oxidation mechanisms in dispersed phases of structural matrixes with heterogeneous composition have not yet been established (Partanen et al., 2008). If the components of a product have discriminatory power, their concentrations can form a characteristic pattern or fingerprint related to the

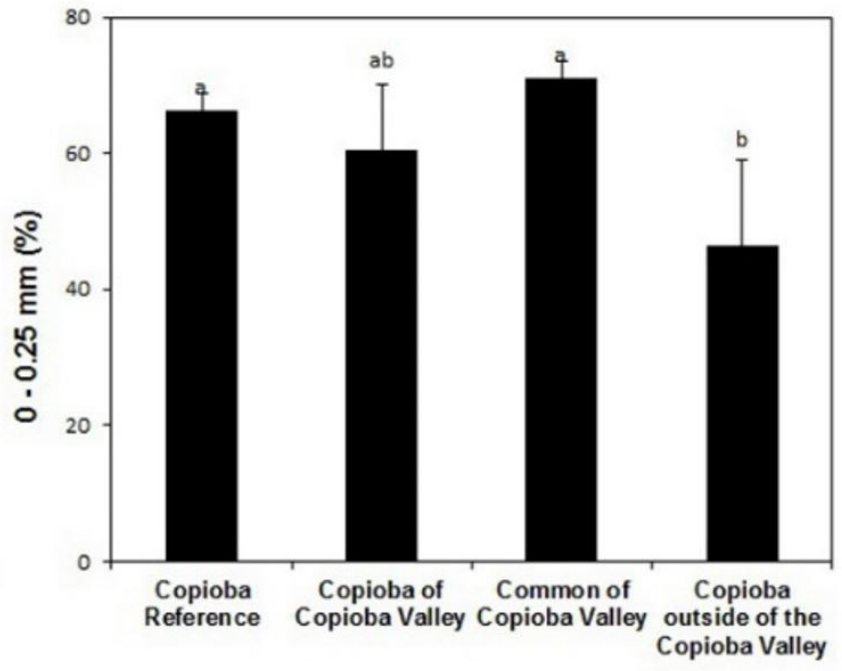

Figure 2. Particle size distribution of cassava flour samples based on the percentages of particles. 


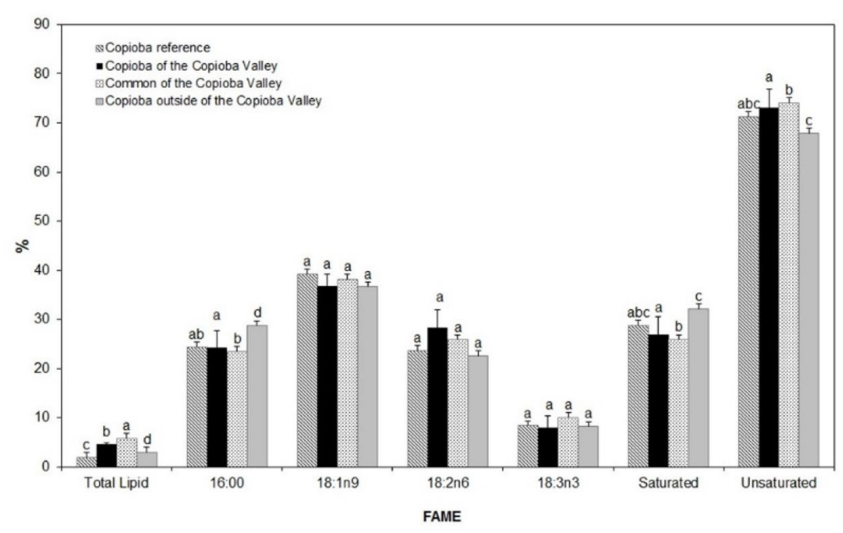

Figure 3. Levels of total lipids (x10) and saturated, unsaturated and total individual lipids in different cassava flours.

product's geographical or human origin (Zhao et al., 2012; Melucci et al., 2016). Volatile compounds are decisive in this area. The secondary products formed by hydroperoxide cleavage, such as aldehydes, have profound impacts on sensory and functional properties (Frankel et al., 1992; Jeong et al., 2010).

The difference between the volatile compound profiles were essentially quantitative. Four aldehydes were identified by Headspace-GC-MS in the volatile fractions of most samples, indicating significant oxidation of the unsaturated fatty acids. This is the case of 2-octenal and 2-decenal present, except in the reference samples (1 and 2), whereas the area of nonanal and decanal were lower than in the reference samples. Oleic acid was also the predominant fatty acid detected in the analyzed flours (Figure 3). These fatty acids have also been identified in chestnut flours, for which soft heating for a relatively long period under oxidizing conditions may be sufficient to induce lipid peroxidation, followed by degradation into aldehydes and ketones (Vasconcelos et al., 2007). All aldehydes in the cassava flours were linear-chain aldehydes (Table 1), in accordance with previous reports in the literature (Sayaslan et al., 2000; RosalesSoto et al., 2016). Aromatic aldehydes were not detected, likely due to the low degradation of aromatic amino acids under the drying conditions used. A wide range of secondary oxidation products can be formed from hydroperoxides originating from primary fatty acid oxidation, such as saturated and unsaturated aldehydes, ketones and hydrocarbons, in addition to lactones, alcohols, acids and esters (Frankel et al., 1992; Zhao et al., 2012).

The major MS-identified compounds in the volatile profiles of the cassava flours were aldehydes (73.18 to $93.34 \%$ of the total area), followed by 3,5-octadien-2-one (6.66 to $26.82 \%$ ). Nonanal was the major component of all analyzed samples ( 48.28 to $62.49 \%$ of total volatiles), and intermediate percentages of 2-octenal (9.03 to $16.50 \%$ ), decanal (11.04 to $12.67 \%$ ) and 2-decenal (1.92 to $10.14 \%$ ) were observed, depending on the treatment and origin. The peak areas of volatile aldehydes were significantly smaller $(p<0.05)$ for samples of the reference Copioba flour produced in the Valley. This finding may be attributable to the lower total lipid concentrations, in association with the average $a_{w}$ value of approximately 0.27 to 0.37 (Table 1 ), resulting from the technological treatment. By contrast, the largest areas of the total volatile peaks $\left(38.24\right.$ to $68.69 \times 10^{6}$ ) associated with higher total lipid contents $(0.53$ to $0.62 \%)$ and lower $\mathrm{a}_{\mathrm{w}}(0.1$ to 0.2$)$ were observed for the Common flours (Table 1).

More volatile compounds may be removed during drying, and the compounds that do not volatilize are those remaining in the flour that are absorbed by the dry food. This process has affects the flour flavor and modifies its nutritional and physiological properties. The volatile compounds 2-octenal, 3,5-octadien-2-one, nonanal and 2-decenal are responsible for green, fat, aldehyde and waxy flavors, respectively, in flour (Cirlini et al., 2012). Aldehydes and ketones resulting from lipid peroxidation degradation have also been identified in cassava starch (Sayaslan et al., 2000; Cirlini et al., 2012). Pentanal, hexanal, nonanal, 2-octenal, 2,4-heptadienal, 2-nonenal, 2,4-decadienal and 2,4-nonadienal contribute to an unpleasant boiled potato flavor (Petersen et al., 1999). In general, the flavors that develop during drying processes are described as characteristic of fruit, grass, buttery, burned, nut and fish, and oxidation of linoleic acid increases the fish odor and decreases the fruit odor. Studies have reported a strong correlation between off-flavors and higher concentrations of 2-pentenal, 2-hexenal, 2-heptenal, 2-pentylfuran and 2-decenal in products subjected to drying (Blanda et al., 2010).

\subsection{Correlations and multivariate analysis}

The Spearman rho analysis of the correlations between different volatile compounds revealed directly proportional correlations greater than 0.8 between $24.4 \%$ of the volatiles. Moreover, the peak areas of volatile compounds were correlated with $\mathrm{a}_{\mathrm{w}}$ (Figure 4). The Common flours samples showed higher amounts of volatile compounds and the $\mathrm{a}_{\mathrm{w}}$ value was less than 0.25 . The correlations between the peaks areas of all or individual volatile compounds and $\mathrm{a}_{\mathrm{w}}$ used a second-order polynomial mathematic model typical of lipid oxidation, obtained $\mathrm{R}^{2}$ values greater than 0.6.

In general, lipid oxidation is lower at $\mathrm{a}_{\mathrm{w}}$ values closer to the water monolayer (0.2 - 0.3 for most foods), due to a decrease in the catalytic effect of transition metals, free radical and o oxygen extinction and a decrease in hydroperoxide decomposition. However, lipid oxidation rates increase rapidly at $\mathrm{a}_{\mathrm{w}}$ values higher or lower than the water monolayer (Jeong et al., 2010; Kulchan et al., 2010; Zhao et al., 2012), especially during flour processing and/or storage. The quality of cassava flours can be greatly affected by small changes in $\mathrm{a}_{\mathrm{w}}$ over the range of 0.1 to 0.6 and, consequently, by oxidative stability and volatile formation, with changes in flavor and the appearance of rancidity. The quality of cassava flours and their differentiation or notoriety may be related to fatty acid oxidation products, since volatile production was lower at $\mathrm{a}_{\mathrm{w}}$ values between 0.2 and 0.4 , moderates at $\mathrm{a}_{\mathrm{w}}$ values between 0.4 and 0.6 and higher at $\mathrm{a}_{\mathrm{w}}$ values lower than 0.2 . Considering that the volatile concentration depends on the $\mathrm{a}_{\mathrm{w}}$ of cassava flours, following a typical oxidation curve, $\mathrm{a}_{\mathrm{w}}$ may potentially indicate flour quality and be used as an indicator of drying performance and process quality. 
The PCA analyzes were performed observing the recognition of patterns associated with the geographical location of the samples, using the same quantitative variables: $a_{w}$, total lipids, particle size (up to $0.425 \mathrm{~mm}$ ), C16:0. The PC1 explains 55.73\% of the data, while PC2 explains $25.40 \%$, a total variance of $81.13 \%$ (Figure 5A). Samples CCV1 and CCV2 (reference) were similar in the main components showing pattern in the values of the analyzed variables. Samples CCV3 to CCV10 had characteristics similar and close to the references, with moderate water activity and low palmitic acid percentage. Samples CMCV1 to CMCV4 were grouped with characteristics of high percentage of total lipids and high percentage of particle size less than $0.045 \mathrm{~mm}$ in addition low percentage of palmitic acid and water activity. The samples COCV 1 to COCV6 showed high concentrations of palmitic acid and moderate $a_{w}$ values. This result suggests that the study's quantitative variables can be used as an index for determining the geographic origin and processing of cassava flour.

In dendrogram, the samples were divided in four main clusters using distance 10 (Figure 5). One cluster includes reference Copioba cassava flours CCV1 and CCV2 and more CCV4, CCV5, CCV7, CCV8, CCV10 and one CMCV2. Other cluster is formed by CCV3, CCV9, CMCV3, CMCV4 and $\mathrm{CMCV} 1$ samples. These first two groups form a larger cluster if
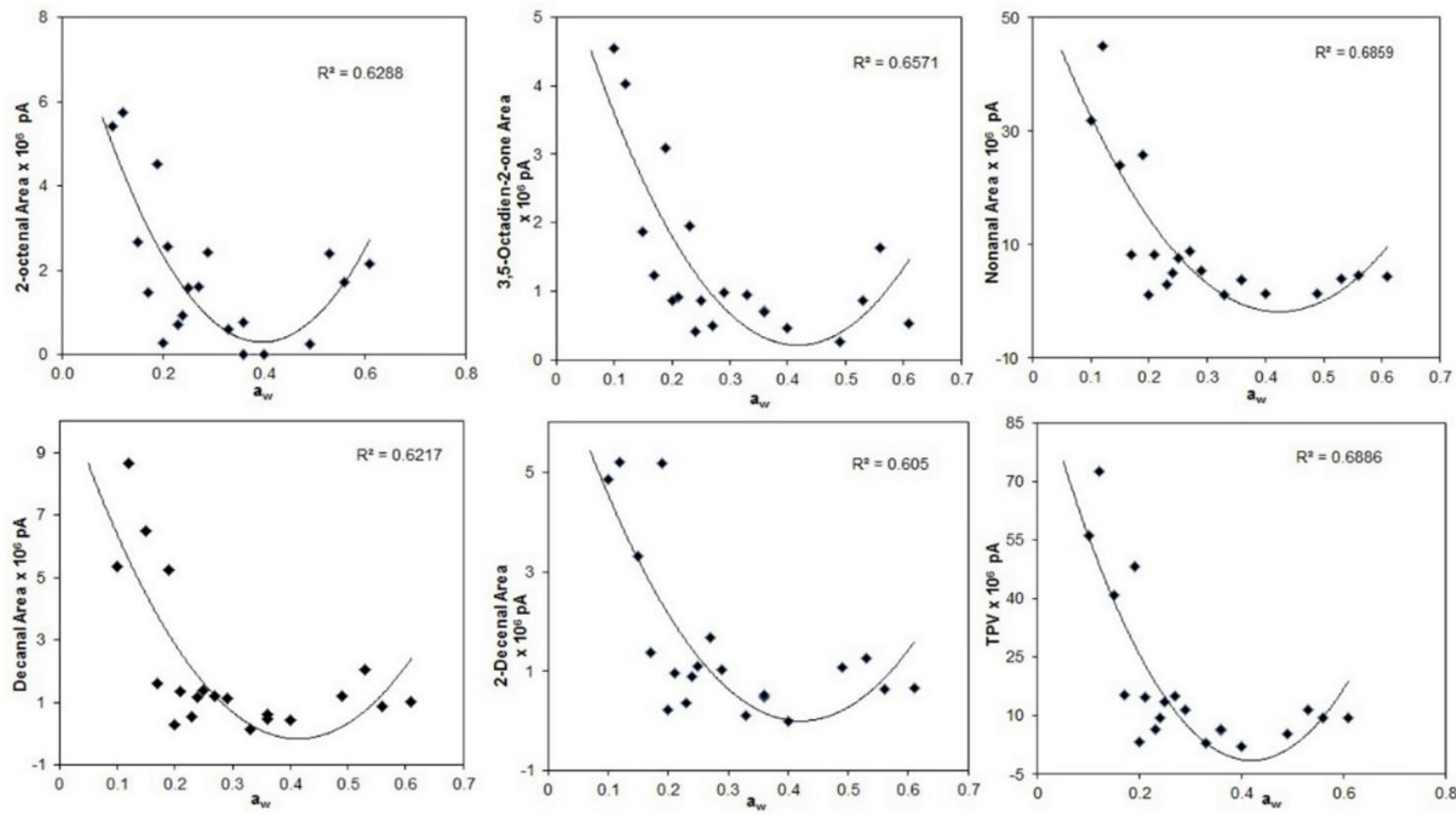

Figure 4. Two-dimensional scatter plot of quantitative variables $\mathrm{a}_{\mathrm{w}}$ and volatile compound (peak area x $10^{6} \mathrm{pA}$ ). TAV = Total Area of Volatiles.

A)

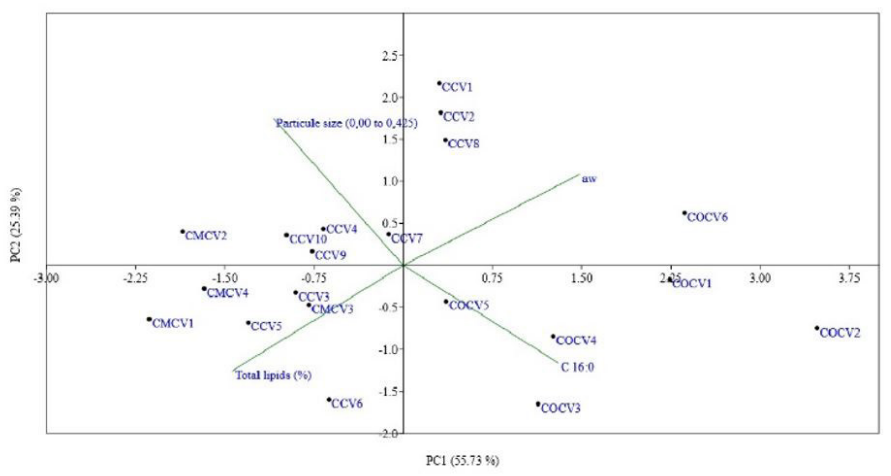

B)

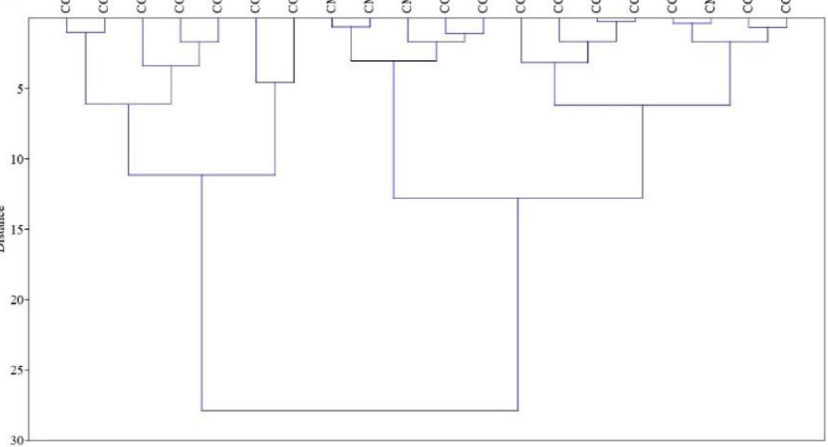

Figure 5. A) PCA scores plot of responses to Copioba cassava flours from inside the CV (CCV, samples 1 to 10), Common cassava flours from inside the CV (CMCV, samples 11 to 14); and Copioba cassava flours from outside the CV (COCV, samples 15 to 20) with principal components PC1, PC2, PC3 and PC4; B) Dendrograms showing the results of the cluster analysis of the twenty flour samples. 
was considered a distance of 15 . Finally, the other two clusters involving COCV samples, with only one sample from $\mathrm{CV}$, the CCV6, that remained in this group. In general, the samples from the same geographical origin showed greater similarity in the analysis of the dendrogram.

Copioba cassava flours have greater notoriety because are processed at lower temperatures and rotation speeds and feature smaller-sized particles (up to $0.425 \mathrm{~mm}$ ), less unsaturated lipids (\%) and total volatiles (\%) and $\mathrm{a}_{\mathrm{w}}$ values between 0.27 and 0.41 . Small-scale drying and processing methods may be the best ways of preparing Copioba flour. New drying methods should be tested to replace the artisanal method with the goal of increasing the production scale while maintaining quality.

Similar to many popular goods with their own unique characteristics, Copioba flour has been copied, and forgeries are common. Each "flour house" features unique aspects of different stages of the production process due to differences in knowledge and abilities transmitted over generations, although they all use a production process that is common in the Copioba Valley and Bahia's Reconcavo. In this region, the most important modification has been the introduction of electric equipment for grating and drying to facilitate processing. Our results indicate that "Copioba Valley" can be used as a geographical indication for Copioba cassava flours produced in this region based on their characteristic composition.

\section{Conclusion}

Reference Copioba cassava flours produced in the CV were obtained using a traditional process, characterized by a soft drying stage in 3 wood-fired ovens with manual controls, followed by 3 consecutive alternating cycles of sieving. Copioba flours produced both inside and outside the Copioba Valley, although they include only 1 drying cycle in an electric oven and 1 sieving cycle, use lower temperatures with a gradual increase in temperature for longer periods of time. Higher total and unsaturated lipid percentages were associated with higher volatile percentages, mainly nonanal, which are products of fatty acid oxidation. Copioba flours presented a lower area of total volatiles, especially nonanal, compared with Common flours, and this lower total volatile content was associated with lower total lipid concentrations and $\mathrm{a}_{\mathrm{w}}$ values between 0.27 and 0.41 , a range over which oxidation is slower. The Common flours had higher volatile and total lipid concentrations and $\mathrm{a}_{\mathrm{w}}$ values between 0.1 and 0.25 , a range over which oxidation is faster. Therefore, $\mathrm{a}_{\mathrm{w}}$ is an important control factor in the production process and in determining the characteristics and stability of Copioba flours. The distribution according to geographic origin and type of process was studied by PCA using significant quantitative variables, namely: $\mathrm{a}_{w}$ particle size (up to $0.425 \mathrm{~mm}$ ), total lipids and palmitic acid (C16:0). The differences are associated with the different drying temperatures used in the 2 different flour processing methods. These results should be further explored not only for the commercial classification of the Copioba flour but also to promote the product's PGI registration.

\section{Acknowledgements}

This work was supported by FABESB-TSC 0027/2011 (Brazil). D.R.C. Pascoal acknowledges a CAPES MSc. Scholarship. The authors also acknowledge the cooperation of the producers of the Copioba Valley.

\section{References}

Anderson, K. A., \& Smith, B. W. (2002). Chemical profiling to differentiate geographic growing origin of coffee. Journal of Agricultural and Food Chemistry, 50(7), 2068-2075. http://dx.doi.org/10.1021/jf011056v. PMid:11902958.

Aryee, F. N. A., Oduro, I., Ellis, W. O., \& Afuakwa, J. J. (2006). The physicochemical properties of flour samples from the roots of 31 varieties of cassava. Food Control, 17(11), 916-922. http://dx.doi. org/10.1016/j.foodcont.2005.06.013.

Association of Official Analytical Chemists - AOAC. (2005). Official methods of analysis of the AOAC International (18th ed.). Arlington: AOAC.

Blanda, G., Cerretani, L., Comandini, P., Toschi, T. G., \& Lercker, G. (2010). Investigation of off-odour and off-flavour development in boiled potatoes. Food Chemistry, 118(2), 283-290. http://dx.doi. org/10.1016/j.foodchem.2009.04.135.

Bligh, E. G., \& Dyer, W. J. (1959). A rapid method of total lipid extraction and purification. Canadian Journal of Biochemistry and Physiology, 37(8), 911-917. http://dx.doi.org/10.1139/o59-099. PMid:13671378.

Brasil, Ministério da Agricultura Pecuária e Abastecimento - MAPA. (2013). Sustainable development geographical indication potential products, Brazil. Retrieved from http://www.agricultura.gov.br/ desenvolvimento-sustentavel/indicacao-geografica/produtospotenciais/bahia.

Brasil, Ministério da Agricultura, Pecuária e Abastecimento. (2011). Regulamento técnico da farinha de mandioca. Instrução Normativa no 52 de 07 de novembro de 2011. Diário Oficial da Republica Federativa do Brasil.

Burns, A. E., Gleadow, R. M., Zacarias, A. M., Cuambe, C. E., Miller, R. E., \& Cavagnaro, T. R. (2012). Variations in the chemical composition of cassava (Manihot esculenta Crantz) leaves and roots as affected by genotypic and environmental variation. Journal of Agricultural and Food Chemistry, 60(19), 4946-4956. http://dx.doi.org/10.1021/ jf2047288. PMid:22515684.

Charles, A., Sriroth, K., \& Huang, T. (2005). Proximate composition. mineral contents. hydrogen cyanide and phytic acid of 5 cassava genotypes. Food Chemistry, 92(4), 615-620. https://doi.org/10.1016/j. foodchem.2004.08.024.

Cirlini, M., Dall'Asta, C., Silvanini, A., Beghè, D., Fabbri, A., Galaverna, G., \& Ganino, T. (2012). Volatile fingerprinting of chestnut flours from traditional Emilia Romagna (Italy) cultivars. Food Chemistry, 134(2), 662-668. http://dx.doi.org/10.1016/j.foodchem.2012.02.151. PMid:23107676.

Dias, L. T., \& Leonel, M. (2006). Physic-chemical characteristics of cassava flours from different regions of Brazil. Ciência e Agrotecnologia, 30, 692-700. http://dx.doi.org/10.1590/S1413-70542006000400015.

Food and Agriculture Organization - FAO. (1989). Stand Codex. 1761989 - Codex standard for edible cassava flour. Retrieved from http:// www.fao.org/fao-who-codexalimentarius.

Frankel, E. N., Selke, E., Neff, W. E., \& Miyashita, K. (1992). Autoxidation of polyunsaturated triacylglycerols. IV - Volatile decomposition 
products from triacylglycerols containing linoleate and linolenate. Lipids, 27(6), 442-446. http://dx.doi.org/10.1007/BF02536386. PMid:27519670.

Gleadow, R. M., \& Møller, B. L. (2014). Cyanogenic glycosides: synthesis, physiology, and phenotypic plasticity. Annual Review of Plant Biology, 65(1), 155-185. http://dx.doi.org/10.1146/annurevarplant-050213-040027. PMid:24579992.

Hammer, Ø., Harper, D. A. T., \& Paul, D. R. (2001). Past: Paleontological Statistics Software Package for Education and Data Analysis. Palaeontologia Electronica, 4(1), 1-9. http://palaeo-electronica. org/2001_1/past/issue1_01.htm.

Instituto Adolfo Lutz - IAL. (2008). Normas Analíticas do Instituto Adolfo Lutz: métodos químicos e físicos para análises de alimentos. São Paulo: IAL.

Jeong, M. K., Lee, J. M., Cho, W.-I., \& Lee, J. H. (2010). Correlation of volatiles and fatty acids in thermally oxidized fatty acid model systems using statistical approaches. Food Science and Biotechnology, 19(5), 1233-1239. http://dx.doi.org/10.1007/s10068-010-0176-x.

Joseph, J. D., \& Ackman, R. G. (1992). Capillary column gas chromatography method for analysis of encapsulated fish oil and fish oil ethyl esters: collaborative study. Journal of AOAC International, 75(3), 488-506. http://dx.doi.org/10.1093/jaoac/75.3.488.

Kojima, T. I., Horigane, A. K., Nakajima, H., Yoshida, M., \& Nagasawa, A. (2004). T2 Map, moisture distribution, and texture of boiled japanese noodles prepared from different types of flour. Cereal Chemistry, 81(6), 746-751. http://dx.doi.org/10.1094/CCHEM.2004.81.6.746.

Kulchan, R., Boonsupthip, W., \& Suppakul, P. (2010). Shelf life prediction of packaged cassava-flour-based baked product by using empirical models and activation energy for water vapor permeability of polyolefin films. Journal of Food Engineering, 100(3), 461-467. http:// dx.doi.org/10.1016/j.jfoodeng.2010.04.031.

Manly, B. F. J. (2006). Randomization, bootstrap and Monte Carlo methods in biology (3rd ed., pp. 460-461). Flórida: Chapman \& Hall.

Melucci, D., Bendini, A., Tesini, F., Barbieri, S., Zappi, A., Vichi, S., Conte, L., \& Toshi, T. G. (2016). Rapid direct analysis to discriminate geographic origin of extra virgin olive oils by flash gas chromatography electronic nose and chemometrics. Food Chemistry, 204, 263-273. http://dx.doi.org/10.1016/j.foodchem.2016.02.131. PMid:26988501.

Olsen, K. M., \& Schaal, B. A. (1999). Evidence on the origin of cassava: phylogeography of Manihot esculenta. Proceedings of the National Academy of Sciences of the United States of America, 96(10), 55865591. http://dx.doi.org/10.1073/pnas.96.10.5586. PMid:10318928.

Partanen, R., Raula, J., Seppänen, R., Buchert, J., Kauppinen, E., \& Forssell, P. (2008). Effect of relative humidity on oxidation of flaxseed oil in spray dried whey protein emulsions. Journal of Agricultural and Food Chemistry, 56(14), 5717-5722. http://dx.doi.org/10.1021/ jf8005849. PMid:18572915.

Petersen, M. A., Poll, L., \& Larsen, M. L. (1999). Identification of compounds contributing to boiled potato off-flavour "POF". Lebensmittel-Wissenschaft + Technologie, 32(1), 32-40. http://dx.doi. org/10.1006/fstl.1998.0506.

Rosales-Soto, M. U., Gray, P. M., Fellman, J. K., Mattinson, D. S., Ünlü, G., Huber, K., \& Powers, J. R. (2016). Microbiological and physicochemical analysis of fermented protein fortified cassava (Manihot esculenta Crantz) flour. Food Science and Technology, 66, 355-360.

Sayaslan, A., Chung, O. K., Seib, P. A., \& Seitz, L. M. (2000). Volatile compounds in five starches. Cereal Chemistry, 77(2), 248-253. http:// dx.doi.org/10.1094/CCHEM.2000.77.2.248.

Serviço Brasileiro de Apoio às Micro e Pequenas Empresas - SEBRAE. (2021). Overview of registered Brazilian GIs. Retrieved from https:// datasebrae.com.br/panorama-das-igs-brasileiras/.

Silva, I. R. C., Cardoso, R. C. V., Góes, J. A. W., Druzian, J. I., Vidal, P. O. Jr., \& Andrade, A. C. B. (2017). Food safety in cassava "flour houses" of Copioba Valley, Bahia, Brazil: diagnosis and contribution to geographical indication. Food Control, 72, 97-104. http://dx.doi. org/10.1016/j.foodcont.2016.07.034.

Su, S., Wang, L. J., Feng, C. Y., Liu, Y., Li, C. H., Du, H., Tang, Z. Q., Xu, Y. J., \& Wang, L. S. (2016). Fingerprints of anthocyanins and flavonols of Vaccinium uliginosum berries from different geographical origins in the Greater Khingan Mountains and their antioxidant capacities. Food Control, 64, 218-225. http://dx.doi.org/10.1016/j. foodcont.2016.01.006.

Vasconcelos, M. D. C. B. M., Bennett, R. N., Rosa, E. A. S., \& Cardoso, J. V. F. (2007). Primary and secondary metabolite composition of kernels from three cultivars of Portuguese chestnut (Castanea sativa Mill.) at Different Stages of Industrial Transformation. Journal of Agricultural and Food Chemistry, 55(9), 3508-3516. http://dx.doi. org/10.1021/jf0629080. PMid:17407304.

Xu, L., Yu, X., Liu, L., \& Zhang, R. (2016). A novel method for qualitative analysis of edible oil oxidation using an electronic nose. Food Chemistry, 202, 229-235. http://dx.doi.org/10.1016/j.foodchem.2016.01.144. PMid:26920289.

Yao, Y., Zhang, J., \& Ding, X. (2003). Retrogradation of starch mixtures containing rice starch. Journal of Food Science, 68(1), 260-265. http:// dx.doi.org/10.1111/j.1365-2621.2003.tb14149.x.

Zhao, H., Guo, B., Wei, Y., \& Zhang, B. (2012). Effects of wheat origin, genotype, and their interaction on multielement fingerprints for geographical traceability. Journal of Agricultural and Food Chemistry, 60(44), 10957-10962. http://dx.doi.org/10.1021/jf3021283. PMid:23057662. 